\title{
On the habitat and isolation of Gymnocharacinus bergi (Osteichthyes: Characidae)
}

\author{
Roberto C. Menni ${ }^{1} \&$ Sergio E. Gómez ${ }^{2}$ \\ ${ }^{\prime}$ Museo de La Plata, Paseo del Bosque s/n, 1900, La Plata, Argentina \\ ${ }^{2}$ Instituto de Limnología 'Dr. R.A. Ringuelet', Casilla de Correo 712, 1900, La Plata, Argentina
}

Received 13.4.1993 Accepted 3.2.1994

Key words: Thermal water, Water chemistry, Zoogeography, Fish ecology, Patagonia, Neotropical, Ostariophysi

\section{Synopsis}

Gymnocharacinus bergi is a rare Paranensean fish which is the only characiform almost lacking scales in the adult. It is endemic and the only species in a peculiar spot - a tributary of the Valcheta creek - in the Somuncurá plateau in northern Patagonia, Argentina, over $300 \mathrm{~km}$ from the nearest place with a paranensean fish fauna. Besides its geographical isolation, $G$. bergi occurs within an area with climatic features drastically different from those currently associated with fishes from Neotropical temperate zones. We tested the assumption that water temperature in the naked characin habitat do not agree with the northern Patagonia climate. We also considered the isolation of $G$. bergi within the framework of an increasing inpoverishment of the paranensean ichthyofauna along a NE-SW axis in the Buenos Aires province. For this we applied a decrement equation used in island biogeography. Our findings demonstrate that the existence of $G$. bergi in its isolated habitat is possible because of the thermal traits of the water at the sources of the creeks, its temperature being independent of the climate of the area. The chemical composition of water was found to be within the range of common environments in the Buenos Aires 'pampas' inhabited by several species of Paranensean fishes. Geographically, G. bergi lives in the last of a series of habitats which show a decreasing number of species correlated with the increasing distance from the La Plata River. Conservation status of the species is briefly discussed.

\section{Introduction}

Gymnocharacinus bergi Steindachner, 1903, a unique characoid fish with almost no scales, has an isolated distribution in a small tributary near the headwaters of the Valcheta Creek in the Somuncurá Plateau in Argentina. The Valcheta Creek is in northern Patagonia $\left(40^{\circ} 50^{\prime} \mathrm{S}, 66^{\circ} 40^{\prime} \mathrm{W}\right), 329 \mathrm{~km}$ from the nearest locality with paranensean fishes, which is the Colorado River. Thus this species is the southernmost characid of the world. Its small population (personal observation), isolated distribu- tion and still unsolved phylogenetic relationships (Gery 1978) makes G. bergi an appealing fish for study.

López et al. $(1981,1982,1987,1989)$ quoted no less than 24 references in which the species is mentioned. Important contributions by Gery (1978) and Miquelarena \& Arámburu (1983) referred to osteology. Lüling (1978a, b, c, d) dedicated several papers to the natural history of G. bergi. Pozzi (1936) included a detailed description, measurements and a photograph.

During a 1979 trip when the material cited by Mi- 


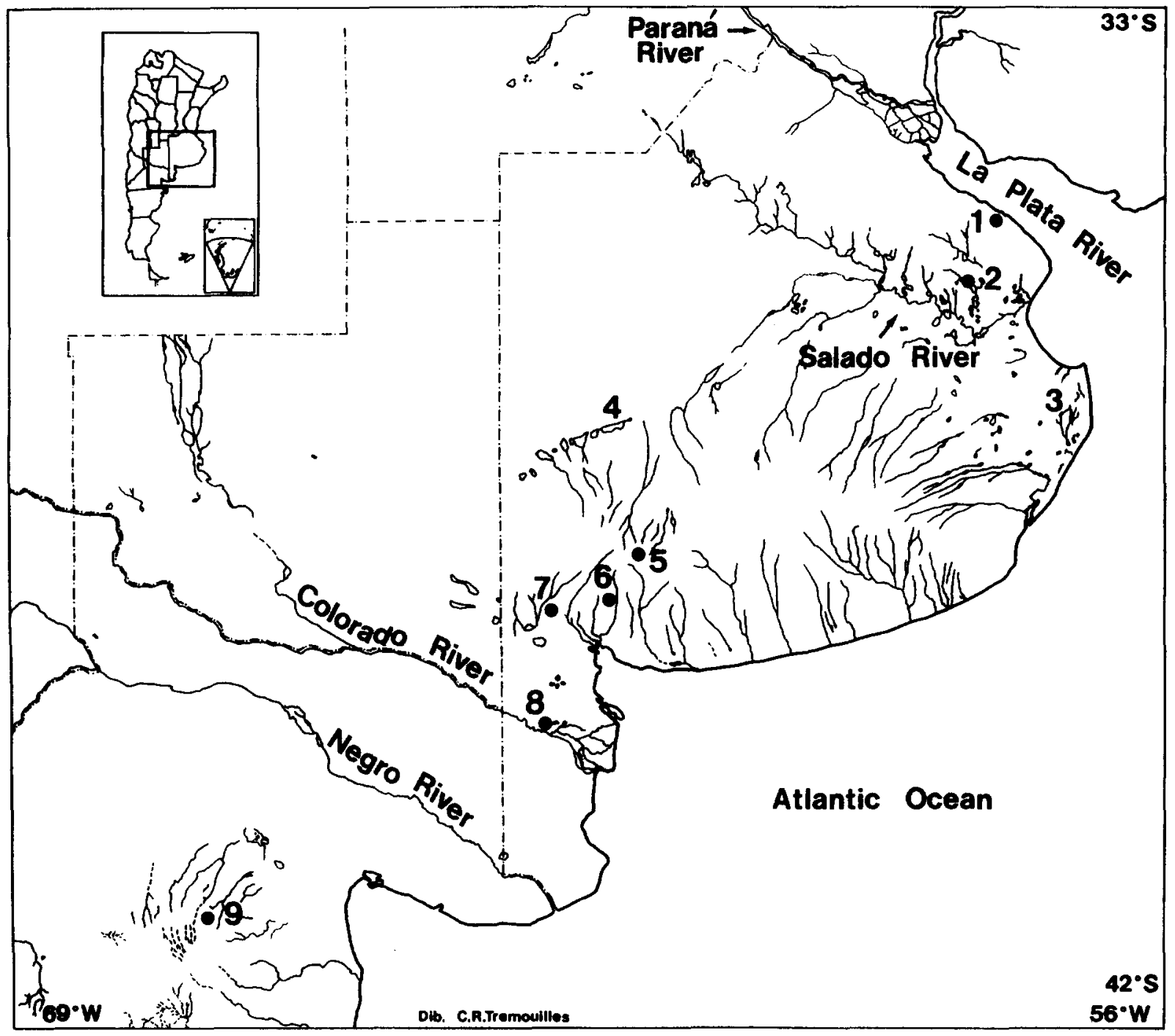

Fig. 1. Province of Buenos Aires and Northern Patagonia (Argentina) displaying Pampasic 'lagunas', Sierra de la Ventana and the Somuncurá Plateau. Locality numbers refer to Table 1.

quelarena \& Arámburu (1983) was collected, the senior author gathered samples and data about water characteristics from the naked characin habitat.

We analyzed temperature and chemistry of water from the G. bergi habitat, to determine if this water is thermal and could explain the presence of the species in its isolated location. A comparison was also made with the water chemistry and ichthyofauna of Sierra de la Ventana and other localities within the Buenos Aires province to consider the distribution of $G$. bergi in a wider faunal and ecological background. Sierra de la Ventana is the nearest area with a variety of lotic habitats occupied by several Paranensean species.

\section{Material and methods}

Topographic references are based on Military Geographic Institute charts N 4166-14 and 4166-15. Linear regressions between pairs of variables were calculated by the least squares method, and the correlation coefficient according to Sokal \& Rohlf (1979). An exponential decrement equation (Mac- 

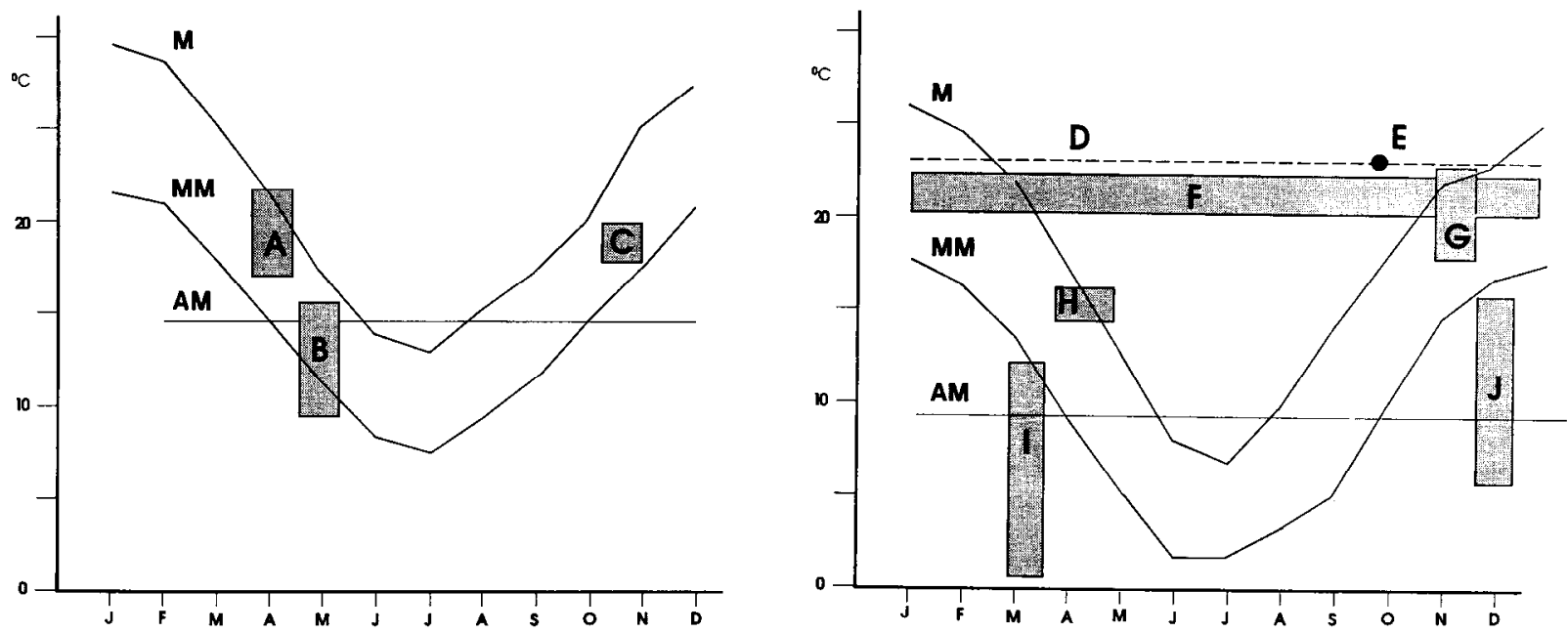

Fig. 2. Annual variation of temperature $\left({ }^{\circ} \mathrm{C}\right)$, air $(\mathrm{M}, \mathrm{MM}, \mathrm{AM})$ and water $(\mathrm{A}, \mathrm{J})$ in Sierra de la Ventana (left) and the Somuncurá Plateau (right). $\mathrm{I}$ and $\mathrm{J}$ localities without $G$. bergi. $\mathrm{M}=$ monthly mean maximum, $\mathrm{MM}=$ monthly mean, $\mathrm{AM}=$ annual mean. $\mathrm{A}=\mathrm{April} 1983$ (Menni et al. 1988), B = May 1987 (Gómez pers. comm.), $\mathrm{C}=$ November 1979 (Menni et al. 1988), $\mathrm{D}=$ '22.5 to $22.6^{\circ} \mathrm{C}$ all the year', Valcheta Creek (Lüling 1978d), $\mathrm{E}=$ October 1975, Valcheta Creek (Lüling 1978c), F = '20 to $22^{\circ} \mathrm{C}$, also in winter months', El Rincón creek (Cei 1980), G = November 1979, Estancia El Rincón y Chipauquil (Miquelarena \& Arámburu 1983), H = April 1968, Quebrada de El Rincón (Cei 1969), I = March 1968, Raimunda pond (Cei 1969), J = December 1967, Raimunda pond (Cei 1969).

Arthur \& Wilson 1967, Pianka 1982), was used to describe the impoverishment of the Parenensean fish fauna along a NE-SW axis in the southern Pampasia. Air temperature data were obtained at the Maquinchao station, at $800 \mathrm{~m}$ above sea level (a.s.l.), an elevation very close to that of Valcheta Creek sources. Climate data for Sierra de la Ventana are values for the city of Sierra de la Ventana station. Chemical analysis were done at the Water Chemistry Laboratory of the Instituto de Limnologia de La Plata, according to APHA $(1985)^{3}$ methods.

The Somuncurá Plateau (Fig. 1) (Cei 1969) has a surface of $15000 \mathrm{~km}^{2}$. It is roughly ellipsoid and is located between $40^{\circ} 50^{\circ}$ and $41^{\circ} 45^{\prime} \mathrm{S}$ and $66^{\circ}$ and $68^{\circ} \mathrm{W}$. It was formed as a result of volcanic activity during the Mio-Pliocene. Neither the Entrerriana ingression nor the glaciations seem to have affected its characteristics. Three altitude levels or floors are recognized within the plateau, related to the morpho-hydrological features: the volcanic heights, between 1500 and $2000 \mathrm{~m}$; the lowland floor of the

\footnotetext{
${ }^{3}$ American Public Health Association. 1985. Standard methods for the examination of water and wastewater. American Public Health Assoc., Washington.
}

clay ponds between 900 and $1500 \mathrm{~m}$; and the "quebradas' or filter creeks floor, between 500 and $900 \mathrm{~m}$. The Valcheta Creek headwaters, where $G$. bergi lives, are placed at the latter level, which is also inhabited by the endemic (Cei1969,1980) anuran Telmatobios somuncurensis. The naked characin specimens studied here were collected at few meters of tributary origin. The source of the water is a limnocrene in the sense of Ringuelet (1962), i.e. surfacing waters forming first a small lentic water body which then produces a small lotic course.

The fauna of the Somuncurá Plateau has a zoogeographic relict character, because of the degree of adaptation and high endemism, particularly evident in the Telmatobiinae (Amphibia). The plateau vegetation is ecotonal between the Patagonic and Monte formations (Cei 1969).

\section{Results}

The habitat of Gymnocharacinus bergi

\section{Water temperature}

We consider that the water at the Valcheta Creek tributary inhabited by $G$. bergi is thermal in charac- 


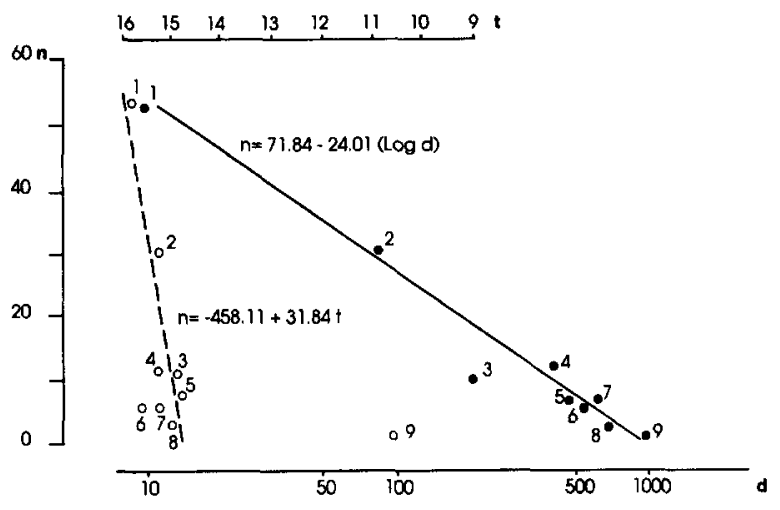

Fig. 3. Regression lines based on data for localities 1 to 8 in Table 1 (Loc. 9 = Valcheta Creek headwaters). Dotted line: regression line between number of permanent species $(n)$ and mean annual temperature $(t)$ for eight localities (open circles) in the Buenos Aires province. Solid line: regression line between number of permanent species $(\mathrm{n})$ and the logarithm of the distance $(\mathrm{km})$ to La Plata harbour (d) for the same eight localities (solid circles) in the Buenos Aires province.

ter. Cei (1969) mentions the presence of G. bergi in the creek origin at El Rincón neighborhood $(700 \mathrm{~m}$ height), stating that at this level temperature during April between 15:00 and 17:00 $\mathrm{h}$ was $15-16^{\circ} \mathrm{C}$. Our temperature data at the Valcheta Creek were obtained during spring, but appeared high for the area; so Miquelarena \& Aramburu (1983) describe it as 'slightly thermal'.

Figure 2 summarizes all available information on air and water temperature for Sierra de la Ventana (left) and Valcheta area (right). Solid lines show monthly maximum means, monthly means and annual means air temperature values. Dotted boxes (and dotted line) represent water temperature values. The range of temperatures at Sierra de la Ventana are very close to the monthly mean air temperature throughout the year (observations for April, May and November: A, B and C, left). This situation is expected when only climatic local factors determine water temperature, which is not the case in the Valchete Creek. Data on water temperature at Valcheta Creek, in localities where $G$. bergi occurs (right, D, E, F, G and H), are similar to, or higher than, the maximum mean monthly air temperature. Data are known for April, October and November. Lüling (1978c, d) states that water temperature is 22.5-22. $6^{\circ} \mathrm{C}$ during the entire year. Cei (1969) explicitly says that water temperature is $20-22^{\circ} \mathrm{C}$ 'al- so in winter months'. Thus we conclude that water in Valcheta Creek is of thermal origin. This conclusion is strengthened by the fact that a lagoon at $1400 \mathrm{~m}$ a.s.l. also in the Somuncurá plateau, has water temperature values below the monthly mean (right, I, J).

\section{Number of species, distance, and temperature}

Past ecological conditions in Patagonia had a marked temperate and moist character, providing conditions for a wider distribution of the Brazilian or Paranensean fauna (Cei 1969, Ringuelet 1975, 1978, 1981). With increasing aridity and lower temperatures in north Patagonia and the southern Pampasia, the Brazilian fauna suffered a marked retraction. This is confirmed for many animal groups (testacean amoebae, leeches, aquatic oligochaetes, bivalves, gastropods, harvestman (Opiliones), many aquatic and terrestrial orders of insects, crustaceans, fishes, amphibians, birds and mammals) by historical, paleontological and ecological data (Ringuelet 1978, 1981).

The presence of $G$. bergi can be related to the present ecological conditions along an environmental gradient across the Buenos Aires province. These conditions were analyzed from two points of view: the relationship between species number and temperature, and the relationship between the number of species and the relative distance to a point with a richer fauna. We selected as this point the Rio de La Plata, which is the source of renewal of fish populations for a variety of environments in the Buenos Aires province under different conditions (communication channels, flooding). Examples of this are man-made ponds studied by Menni $\&$ Almiron (personal communication), and the use of the Salado River by many species as a population corridor to Bonaerensean 'lagunas' (Menni 1984).

For this analysis eight localities are considered, for which the number of permanent fish species is well known (Fig. 1, Table 1). Application of the exponential decrement equation to the number of fishes in the eight localities, taking the Rio de $\mathrm{La}$ Plata as the distance origin, gives the following relationship between the number of species ( $n$ ) and the $\log$ distance $(\log d)$ : 
$\mathbf{n}=71.84-24.01(\log d)$

with $r=-0.991(p<0.01)$. The equation predicts that the 0 number of species is reached at $981 \mathrm{~km}$ from the origin point. The headwaters of the Valcheta Creek are at $992 \mathrm{~km}$ (Fig. 3).

Figure 3 also shows the relationship between the number of species and the mean annual temperature for the eight localities in Table 1. Los Talas $\left(35^{\circ} \mathrm{S}\right)$ is the nothernmost point, and the drainage channels of the Colorado River $\left(39^{\circ} \mathrm{S}\right.$ at the mouth) are the southernmost point (Fig. 1). Using again $\mathrm{n}$ as the number of species and $\mathrm{t}$ as the mean annual temperature, the relationship is:

$$
\mathrm{n}=-458.11+31.84 \mathrm{t}
$$

with $\mathrm{r}=0.9499(\mathrm{p}<0.01)$.

The dotted line in Fig. 3 shows the decreasing number of species with decreasing values of temperature. Lower temperatures correspond to southern localities. Display of Valcheta Creek values (point 9) shows that they do not agree with the calculated equation. This demonstrates that the species number at Valcheta (one) is not the expected for the normal air temperature there (annual mean $9.6^{\circ} \mathrm{C}$ ), a value at which no Paranensean fish can live permanently. The equations predicts zero species at about $14.4^{\circ} \mathrm{C}$ mean annual temperature, which is lower than that of Sierra de La Ventana. All mean values for all localities are slightly above this one, while those for Valcheta are well below
(Table 1). Similar conclusions are reached using minimum annual means $(r=0.9046)$ and the mean temperature of the coldest month of the year (July, $\mathrm{r}=0.8935$ ).

\section{Water chemistry}

Water in the Valcheta Creek section inhabited by $G$. bergi is hypohaline. Due to the $\mathrm{Ca}++$ and $\mathrm{Mg}+$ content it is moderately soft (total hardness 111 to $118.5 \mathrm{mg} \mathrm{CO}_{3} \mathrm{Ca} \mathrm{l}^{-1}$ ). It is of the $\mathrm{CO}_{3} \mathrm{H}-, \mathrm{Na}+$, $\mathrm{Ca}++, \mathrm{Mg}++$ type, slightly alkaline and with a relatively high buffering power in relation to the inorganic carbon system (alkalinity $3.39 \mathrm{meq}^{-1}$ ).

Data available on Valcheta Creek water chemistry include a set from Lüling (1978d) and two sets from samples obtained by RCM during November 1979. These data are in Table 2, together with information from Sierra de La Ventana in the highlands area (Menni et al. 1988), from the middle Paraná River (Bonetto \& Lancelle 1981), from the Vitel pond (Olivier 1961), and from the Chascomus pond (Conzonno \& Claverie 1990). These data are included because Sierra de La Ventana creeks are considered as the nearest environments to Valcheta inhabited exclusively by paranensean fishes.

The Vitel and Chascomús 'lagunas' (permanent ponds, lakes of third order), are typical pampasic environments (Ringuelet 1972, Ringuelet et al. 1967b).

Table 3 shows percentage similarity values among the considered environments, based in the number of factors with overlapped ranges. The pre-

Table 1. Number of permanent species (n), linear distances to La Plata harbour (d, in $\mathrm{km}$ ) and air temperature in ${ }^{\circ} \mathrm{C}(\mathrm{tl}=$ annual mean, $\mathrm{t} 2$ = minimum annual mean, $\mathrm{t} 3=$ July mean) for eight localities in the Buenos Aires province ( 1 to 8$)$ and the headwaters of the Valcheta Creek (9).

\begin{tabular}{lccccc}
\hline Locality & $\mathrm{n}$ & $\mathrm{d}$ & $\mathrm{t} 1$ & $\mathrm{t} 2$ & $\mathrm{t}$ \\
\hline 1. Los Talas & 53 & 6 & 16.0 & 12.0 & 9.7 \\
2. Chascomús 'laguna' & 28 & 80.9 & 15.23 & 9.33 & 8.8 \\
3. Salada Grande 'laguna' & 10 & 242.7 & 14.5 & 10.0 & 8.7 \\
4. Alsina and Cochicó 'lagunas' & 11 & 450.6 & 14.75 & 8.4 & 7.6 \\
5. Sierra de la Ventana & 7 & 500.0 & 14.5 & 7.9 & 7.8 \\
6. Napostá Grande Creek & 6 & 544.9 & 14.7 & 8.45 & 7.85 \\
7. Chasicó creek & 6 & 612.4 & 14.9 & 9.0 & 7.9 \\
8. Drainage channels Colorado River & 3 & 666.3 & 14.5 & 8.5 & 7.25 \\
9. Valcheta Creek headwaters & 1 & 992.0 & 9.6 & 2.1 & 1.9 \\
\hline
\end{tabular}


sent analysis shows that there is no chemical factor with values exclusive for Valcheta.

Though water temperature in Valcheta creeks obviously depends upon geological factors, its chemical composition does not differ markedly from water of Vitel and Chascomus. It is unlikely that the chemical composition of water there has a significant influence on fishes; any more or less eurytopic paranensean fish species could tolerate these values (Menni et al. personal communication). This chemical 'normality' of Valcheta water, indicates that although its temperature is high enough for $G$. bergi to live there, it does not alter the geological substrate and modify its own composition. Ionic content of Valcheta waters are very far from $\mathrm{Cl}-, \mathrm{SO}_{4}-$ and $\mathrm{Na}+$ values of reached by highly thermal waters (idiotrophic in the sense of Ringuelet 1962) from a locality in NW Argentina - with several fish species - where values for those ions are $266.9,556.9$ and $469.7 \mathrm{mg} \mathrm{l}^{-1}$, respectively. Thermal environments inhabited by cyprinodontiform fishes in U.S.A. (Deacon \& Minckley 1974) show the fol- lowing ranges for $\mathrm{Cl}-, \mathrm{SO}_{4}-$ and $\mathrm{Na}+$, respectively: $8.86-21000,40.8-9658$ and $12.9-24440 \mathrm{mg} \mathrm{l}^{-1}$.

\section{Discussion}

Some proposals, based on the assumption that the present distribution of $G$. bergi was not reached by dispersion appear of interest. Ringuelet et al. (1967a), and Ringuelet $(1975,1978,1981)$, have explicitly stated that the presence of $G$. bergi in northern Patagonia indicates a wider distribution of the Paranensean ichthyofauna in the past. Ringuelet supported the hypothesis, now widely accepted, that the increasing aridity of the climate was the major cause of the restriction of that fauna during the Tertiary.

Typical Paranensean fish species are known from a Lower Pleistocene level, near Bahia Blanca (about $39^{\circ} \mathrm{S}$ ), as Pimelodella sp. (nearly identical to P. laticeps) (Pimelodidae) and Callichthys sp. and Corydoras sp. (Callichthyidae) (Cione et al. personal communication). A good indicator of the Para-

Table 2. Chemical data for Valcheta creek tributaries, creeks and 'lagunas' in the Buenos Aires province and the middle Paraná River. A = Paraje Chipauquil (Valcheta Creek), 16-11-1979. B = Establecimiento El Rincón (Valcheta Creek), 16-11-1979. C = Valcheta Creek, 25-10-1975 (Lüling 1978d). D = Creeks in Sierra de La Ventana, November 1979 (Menni et al. 1988). E = 'laguna' Vitel (Salado River basin), 1956-1957 (Olivier 1961). F = 'laguna' Chascomús (Salado River basin), 1983-1985 (Conzonno \& Claverie 1990). G= Middle Paraná River (main course), 1968-1969 (Bonetto \& Lancelle 1981). SC = specific conductivity uS $\mathrm{cm}^{-1}$. TDS (total dissolved solids), anions and cations in $\mathrm{mg} \mathrm{l}^{-1}$. $\mathrm{COD}=$ chemical oxygen demand $\mathrm{mg} \mathrm{O}_{2} \mathrm{l}^{-1}$. Total hardness and total alkalinity in $\mathrm{mg} \mathrm{l}^{-1}$ of $\mathrm{CO}_{3} \mathrm{Ca}$. For $\mathrm{D}, \mathrm{E}, \mathrm{F}$ and $\mathrm{G}$ ranges for the period are shown, but those with * are mean values. Lack of data as -.

\begin{tabular}{|c|c|c|c|c|c|c|c|c|c|c|c|}
\hline \multirow[b]{2}{*}{$\mathrm{SC}$} & \multirow{2}{*}{$\begin{array}{r}\text { A } \\
431\end{array}$} & \multirow{2}{*}{$\begin{array}{r}\text { B } \\
384\end{array}$} & \multirow{2}{*}{$\frac{C}{411}$} & \multicolumn{2}{|r|}{$\mathrm{D}$} & \multicolumn{2}{|r|}{$\mathrm{E}$} & \multicolumn{2}{|r|}{$\mathrm{F}$} & \multicolumn{2}{|c|}{$\mathrm{G}$} \\
\hline & & & & 146 & to 171 & & - & 538.0 & to 818.0 & 49.1 & to 112.0 \\
\hline TDS & 358.6 & 340.2 & - & 181.2 & 208.3 & 762.0 & to 1846.0 & 596.0 & 692.0 & & - \\
\hline $\mathrm{pH}$ & 8.54 & 8.55 & $7.9-8.1$ & 7.97 & 8.27 & 6.5 & 9.8 & 8.0 & 9.0 & 7.2 & 7.7 \\
\hline $\mathrm{CO}_{3}-$ & 0.0 & 0.0 & - & \multicolumn{2}{|c|}{0.0} & 0.0 & 120 & 0.0 & 37.6 & \multicolumn{2}{|c|}{0.0} \\
\hline $\mathrm{CO}_{3} \mathrm{H}-$ & 206.7 & 194.7 & - & 115.4 & 144.2 & 147.6 & 507.5 & 219.8 & 294.5 & 27.3 & 47.6 \\
\hline $\mathrm{Cl}-$ & 21.7 & 20.4 & 28.4 & 6.4 & 9.6 & 147.0 & 517.0 & 96.0 & 138.3 & 2.5 & 16.0 \\
\hline $\mathrm{SO}_{4}--$ & 21.6 & 18.6 & 48.5 & 1.4 & 6.3 & 94.0 & 255.0 & 20.8 & 74.3 & 2.5 & 10.8 \\
\hline $\mathrm{Ca}++$ & 24.5 & 24.5 & 22.0 & 21.2 & 27.7 & 11.0 & 33.0 & 17.2 & 32.2 & 4.4 & 10.0 \\
\hline $\mathrm{Mg++}$ & 14.0 & 15.31 & 13.4 & 4.6 & 7.1 & 14.0 & 30.0 & 5.3 & 23.1 & 2.1 & 4.8 \\
\hline $\mathrm{Na}+$ & 66.7 & 63.3 & - & 23.3 & 25.0 & \multicolumn{2}{|r|}{ - } & 119.7 & 194.4 & 4.1 & 13.6 \\
\hline $\mathrm{K}+$ & 3.4 & 3.4 & - & 0.6 & 1.5 & \multicolumn{2}{|r|}{ - } & 10.3 & 13.0 & 1.0 & 3.0 \\
\hline $\mathrm{COD}$ & 10.0 & 5.6 & 3.2 & 4.3 & 8.7 & 12.0 & 57.0 & 7.7 & 18.7 & 1.9 & 12.3 \\
\hline $\mathrm{Mg} / \mathrm{Ca}$ & 0.94 & 1.02 & 0.99 & 0.29 & 0.55 & 0.72 & 2.09 & \multicolumn{2}{|r|}{$1.10^{*}$} & \multicolumn{2}{|c|}{$0.81 *$} \\
\hline $\mathrm{Mg}+\mathrm{Ca} / \mathrm{Na}+\mathrm{K}$ & 0.79 & 0.87 & - & 1.30 & 1.72 & \multicolumn{2}{|r|}{ - } & & $0.32 *$ & \multicolumn{2}{|c|}{$1.57^{*}$} \\
\hline Total hardness & 118.5 & 123.5 & 110.9 & 71.8 & 89.3 & 94.88 & 205.45 & \multicolumn{2}{|c|}{$109.60^{*}$} & 22.3 & 41.7 \\
\hline Total alkalinity & 169.5 & 159.5 & 155.0 & 94.6 & 118.2 & 125.00 & 584.00 & & $45.95 *$ & \multicolumn{2}{|c|}{$29.90^{*}$} \\
\hline
\end{tabular}


nensean character of this assemblage is also the presence of the aquatic turtle Hydromedusa tectifera. The Patagonian cold temperate water genus Percichthys was also found there (A. Cione personal communication). There are fossil characiforms in the Lower Eocene near the San Jorge Gulf in Patagonia ( $46^{\circ} \mathrm{S}$ ) (Cione 1986).

If the Callichthys sp. belongs in the same or a similar species to $C$. callichthys, mean annual temperature in the environment to which the fossil belonged must have been no less than $16^{\circ} \mathrm{C}$ (Gómez 1993). P. laticeps and Corydoras paleatus still live in the area (Menni et al. 1988).

The present boundary of the Paranensean fish fauna, as proposed by Mac Donagh (1934), is approximately at the latitude of the noted fossil locations, at the south of the Buenos Aires province, somewhat to the south of Sierra de la Ventana. This has been discussed in detail by Ringuelet (1975, 1981). The composition of the Sierra de la Ventana fish fauna is provided by Menni et al. (1988), together with distributional data and environmental parameters, supporting previous hypotheses of Mac Donagh (1934) and Ringuelet (1975).

The Paranensean fauna (fishes included) in the Buenos Aires province exhibits a clear impoverishment roughly from NE to SW. Ringuelet (1975) suggests that this feature is due to decreasing temperature and the progressive salinization of the waters toward the SW of the area. This explanation was contended regarding salinity, but confirmed regarding temperature by Gómez (1993), who obtained evidence of a strong correlation between the num- ber of species and the yearly mean temperature. In spite of the accuracy of these explanations in the present, historical factors as the climate changes, are also likely important to the distribution of $G$. bergi.

The isolated distribution of $G$. bergi can be placed in the context of a progressive desertification of the area between the Buenos Aires province and the Somuncurá Plateau. Consideration of this process as a vicariant event or as an insularity case does not produce any new information for the moment. Weitzman \& Weitzman (1982) stated that assumptions of past distributional limitations based on knowledge of those limitations in recent organisms, although never fully reliable, can greatly help our understanding of the patterns to be discerned by other methods.

Our demonstration of the thermal character of the water explains, from an ecological point of view, why this species remains in its present habitat. This habitat is a peculiar combination of a Sierra de la Ventana type physiography, a pampasic type water chemistry, and a warm constant water temperature. Available information (Menni et al. personal communication) on the ecological ranges of several variables tolerated by Cheirodon interruptus and Jenynsia lineata beg the question of why these species do not accompany $G$. bergi at its isolated spot. If the area covered by the creeks inhabited by $G$. bergi is near the minimum required for a freshwater species (Horn 1972, Welcomme 1979), perhaps this is the result of previous competition.

Restricted distribution and limited habitat of $G$.

Table 3. Similarity between considered localities based in chemical characteristics. Similarity values computed as number of characters with overlapping ranges over total number of compared characters (in parentheses). Letters in parentheses refer to values in Table 2.

\begin{tabular}{|c|c|c|c|c|}
\hline & $\begin{array}{l}\text { Valcheta headwaters } \\
(A+B+C)\end{array}$ & $\begin{array}{l}\text { Sierra de la Ventana } \\
\text { creeks (D) }\end{array}$ & $\begin{array}{l}\text { Vitel and Chascomús } \\
\text { 'lagunas' }(E+F)\end{array}$ & $\begin{array}{l}\text { Maine course of the } \\
\text { Paraná River (G) }\end{array}$ \\
\hline Valcheta headwaters $(A+B+C)$ & 1 & $\begin{array}{l}0.25 \\
(4 / 16)\end{array}$ & $\begin{array}{l}0.62 \\
(10 / 16)\end{array}$ & $\begin{array}{l}0.13 \\
(2 / 15)\end{array}$ \\
\hline Sierra de la Ventana creeks (D) & & 1 & $\begin{array}{l}0.31 \\
(5 / 16)\end{array}$ & $\begin{array}{l}0.47 \\
(7 / 15)\end{array}$ \\
\hline Vitel and Chascomús 'lagunas' $(E+F)$ & & & 1 & $\begin{array}{l}0.27 \\
(4 / 15)\end{array}$ \\
\hline Main course of the Paraná River (G) & & & & 1 \\
\hline
\end{tabular}


bergi implies the possibility of this species being affected by habitat alteration and/or competition. The first possibility is less probable, as human population in the area is scarce and agricultural activities meager. The second one deserves some attention, because it appears that introduced salmonids live in the Valcheta River, a few kilometers downstream of the $G$. bergi habitat. Wegrzyn \& Ortubay (1991) reported informal data implying that $G$. bergi extended in the past downstream to the river, from where they have been displaced by trouts (species no cited), introduced for sport fishing.

The naked characin is the only fish species included in a list of argentinean vertebrates in danger of extinction (Chebez 1993), qualified as an endangered species proposed to the Red Data Book. A proposal for the consideration of the Valcheta area as a Provincial Reservation, in order to protect $G$. bergi, has been submitted to the Rio Negro provincial government (Cussac personal communication). We think that the conservation status of this species should be treated with care. For the moment, an undue emphasis on its protection could lead to an increased interest with undesired results.

\section{Acknowledgements}

We thank the staff of the Chemical Laboratory (ILPLA-MLP) for analysis of our samples and V. Conzonno for help and criticism. To R.H. Arámburu and H.L. López for assistance with field work and discussions on Somuncurá features. A. Almirón and M. García for critical readings. We specially thank A.L. Cione for many suggestions and data on the evolution of climate in Patagonia. This work was funded by a Comisión de Investigaciones Científicas de Buenos Aires grant (field work) and by the Research Project PID 160 from the Consejo Nacional de Investigaciones Científicas.

\section{References cited}

Bonetto, A.A. \& H.G. Lancelle. 1981. Calidad de las aguas del río Paraná medio. Principales características físicas y químicas. Comunicaciones científicas CECOAL 11: 1-22.
Cei, J.M. 1969. La meseta basáltica de Somuncurá, Río Negro. Herpetofauna endémica y sus peculiares equilibrios biocenóticos. Physis 28: 257-271.

Cei, J.M. 1980. Amphibians of Argentina. Monitore Zool. Ital. (NS) Monogr. 2: 1-609.

Chebez, J.C. 1993. Listado de vertebrados argentinos en peligro de extinción. Nuestras aves (Asoc. Ornit. del Plata), Supl. 1: $1-14$.

Cione, A.L. 1986. Los peces continentales del Cenozoico de Argentina. Su significación paleoambiental y paleobiogeográfica. Actas IV Congr. Arg. Paleontología y Bioestratigrafía, Mendoza 2: 101-106.

Conzonno, V.H. \& E.F. Claverie. 1990. Chemical characteristics of the waters of Chascomús pond (Provincia de Buenos Aires, Argentina). Limnological implications. Rev. Bras. Zool. 50: 15-21.

Deacon, J.E. \& W.L. Minckley. 1974. Desert fishes. pp. 385-488. In: G.W. Brown (ed.) Desert Biology, Vol. 2, Academic Press, New York.

Gery, J. 1978. Results of Dr. K.H. Lüling research in Argentina in 1975. The relationships of the naked characin Gymnocharacinus bergi (Pisces, Cypriniformes, Characoidei) from northern Patagonia. Zool. Anz. 205: 403-409.

Gómez, S.E. 1993. Susceptibilidad a diversos factores ecológicos extremos, en peces de la Pampasia bonaerense, en condiciones de laboratorio. pp. 165-174. In: Tesis Doctorales, Resúmenes 1986-1990, Fac. Cienc. nat. y Museo, Univ. Nac. La Plata.

Horn, M.H. 1972. The amount of space available for marine and freshwater fishes. U.S. Fish. Bull. 70: 1295-1297.

López, H.L., R.C. Menni \& R.A. Ringuelet. 1981. Bibliografía de los peces de agua dulce de la Argentina y Uruguay 1967-1981. Biología Acuática 1: 1-100.

López, H.L., R.C. Menni \& R.A. Ringuelet. 1982. Bibliografía de los peces de agua dulce de la Argentina y Uruguay. Suplemento 1982. Biología Acuática 3:1-26.

Loṕez, H.L., R.C. Menni \& R.A. Ringuelet. 1987. Bibliografía de los peces de agua dulce de la Argentina y Uruguay. Suplemento 1986. Biología Acuatica 9: 1-61.

Lopéz, H.L., R.C. Menni \& R.A. Ringuelet. 1989. Bibliografía de los peces de agua dulce de la Argentina y Uruguay. Suplemento 1988. Publ. Ministerio de Asuntos Agrarios y Pesca de la provincia de Buenos Aires, La Plata. 42 pp.

Lüling, K.H. 1978a. Der Schuppensole Messingsalmer (Gymnocharacinus bergi) aus Patagonien. Tetra Informat. 12: 28.

Lüling, K.H. 1978b. Die Wiederentdeckung und die erste Ausstellung des Patagonischen Messingsalmers, Gymnocharacinus bergi, in einem Schanaquarium. Zoologischer Garten 48: 167-176.

Lüling, K.H.1978c. Nuevo hallazgo y nota sobre Gymnocharacinus bergi Steindachner, 1903 (Characidae, Tetragonoperidae). Rev. Biol. del Uruguay 6: 19-29.

Lüling, K.H. 1978d. Wissenschaftliche Ergebnisse des Forschungsaufenthaltes Dr. K.H. Lüling in Argentinien 1975: Uber den Biotop des patagonischen Messingsalmers Gymnocharacinus bergi (Pisces, Characoidei). Zool. Anz. 201: 410. 
Mac Arthur, R.H. \& E.O. Wilson. 1967. The theory of island biogeography. Princeton Univ. Press, Princeton. 203 pp.

Mac Donagh, E.J. 1934. Nuevos conceptos sobre la distribución geográfica de los peces argentinos basados en expediciones del Museo de La Plata. Rev. Mus. La Plata 24: 21-170.

Menni, R.C. 1984. Los peces en el medio marino. Ed. Sigma, Buenos Aires. 169 pp.

Menni, R.C., H.L. López \& R.H. Arámburu. 1988. Ictiofauna de Sierra de La Ventana y Chasicó (Provincia de Buenos Aires, Argentina). Zoogeografía y parámetros ambientales. An. Mus. Hist. nat. Valparaíso 19: 75-84.

Miquelarena, A.M. \& R.H. Arámburu. 1983. Osteología y lepidología de Gymnocharacinus bergi (Pisces, Characidae). Limnobios 2: 491-512.

Olivier, S.R. 1961. Estudios limnológicos en la laguna Vitel (Partido de Chascomús, Bs. Aires-Argentina). Agro. 3: 1-128.

Pianka, E.R. 1982. Ecología evolutiva. Ed. Omega, Barcelona. 365 pp.

Pozzi, A.J. 1936. Nota sobre Gymnocharacinus bergi Steindachner. Physis 12: 161-165.

Ringuelet, R.A. 1962. Ecología acuática continental. Eudeba, Buenos Aires. 138 pp.

Ringuelet, R.A. 1972. Ecología y biocenología del hábitat lagunar o lago de tercer orden de la región Neotropica templada (Pampasia sudoriental de la Argentina). Physis 31: 55-76.

Ringuelet, R.A. 1975. Zoogeografía y ecología de los peces de aguas continentales de la Argentina y consideraciones sobre las áreas ictiológicas de America del Sur. Ecosur. 2: 1-122.
Ringuelet, R.A. 1978. Dinamismo histórico de la fauna Brasîica en la Argentina. Ameghiniana 15: 255-262.

Ringuelet, R.A. 1981. El ecotono faunístico subtropical pampásico y sus cambios históricos. pp. 75-80. In: Symposia, VI Jornadas Argentinas de Zoología, II Biogeografía, La Plata.

Ringuelet, R.A., R.H. Arámburu \& A.A. de Arámburu. 1967a. Los peces argentinos de agua dulce. Comisión de Investigación Científica, Province of Buenos Aires, La Plata. 602 pp.

Ringuelet, R.A., A. Salibián, E. Claverie \& S. Ilhero. 1967b. Limnología química de las lagunas pampásicas (Provincia de Buenos Aires). Physis 27: 201-221.

Sokal, R.R. \& F.J. Rohlf. 1979. Biometría. Principios y métodos estadísticos en la investigación biológica. H. Blume, Madrid. $832 \mathrm{pp}$.

Steindachner, F. 1903. Über einige neue Reptilien und Fischarten des Hofmuseums in Wien. Sitz. Akad. Wiss. Wien 112; 15 22.

Wegrzyn, D. \& S. Ortubay. 1991. Nuestros salmónidos. Dir. Pesca Prov. Rio Negro, Viedma. 120 pp.

Weitzman, S.H. \& M. Weitzman. 1982. Biogeography and evolutionary diversification in Neotropical freshwater fishes, with comments on the refuge theory. pp. 403-422. In: G.T. Prance (ed.) Biological Diversification in the Tropics, Columbia University Press, New York.

Welcomme, R.L. 1979. Fisheries ecology of floodplain rivers. Longman, London. 317 pp. 